研 究

\title{
鉄製粉末冶金材料におけるアクティブディスアセンブリー志向のリサィクル技術の開発
}

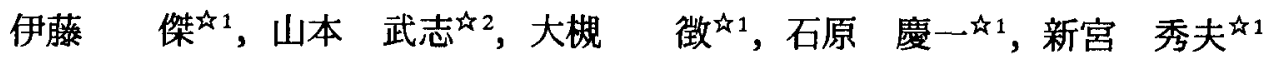 \\ 41 京都大学エネルギー科学研究科, 干606-8501 京都市左京区吉田本町. \\ 2 2 大阪大学大学院工学研究科, 干 565-0871 吹田市山田丘 2-1.
}

\section{New Recyclable Materials based on the Active Dissasembly}

\author{
Suguru Itou $\AA^{\not 1}$, Takeshi Yamamoto ${ }^{\text {h2 }}$, Akira Otsuki ${ }^{\text {म1 }}$, Keiichi N. Ishihara ${ }^{\text {मै1 }}$ and P. Hideo Shingu \\ ${ }^{71}$ Graduate School of Energy Science, Kyoto University, Yoshidahonmachi Sakyo-ku, Kyoto 606-8501. \\ ${ }^{2}$ Fac. Eng., Osaka University, 2-1 Yamadaoka Suita 565-0871.
}

Received September 17, 1999

\begin{abstract}
SYNOPSIS
The purpose of this reseach is to propose a new recycle system of an iron, which is simpler, lower cost and lower energy consumption than the current recycle system. The concept of this system is called "active disassembly" a material includes an actuator which operates under special surroundings. Since large equipment and re-smelting will not be needed, it will be easy to recycle an iron and steel. In this research, Terbium was used as an actuator because rare earth metals have a nature of absorbing hydrogen gas and the volume change during absorbing hydrogen gas. The iron base new material was formed, which includes $\mathrm{Tb}$ actuator network spread into Fe particle boundary during the sintering process. The Tb acutuator was triggered under hydrogen atomosphere and pulverized itself. The material showing the most suitable $\mathrm{Tb}$ network was $\mathrm{Fe}-2 \mathrm{at} \% \mathrm{~Tb}$ sintered at $1673 \mathrm{~K}$ for 600 s and became embrittle after heat treatment under hydrogen atomosphere. The recycled materials can be obtain by sintering the pulverized material again at $1673 \mathrm{~K}$ for $600 \mathrm{~s}$.
\end{abstract}

KEYWORDS

active disassembly, hydrogen, embrittlement

\section{1 緒 言}

鉄鋼材料のスクラップは，製鋼時に発生する自家発生スク ラップと,製品として発生する市中スクラップに分類される. 自家発生スクラップに関しては, 既に製鋼時のリサイクルが 実現されているが，市中スクラップに関しては圧縮，シャー リング, シュレッダーなどの様々な加工工程を経て, 電気炉 による製鋼によって行われている.その際,メッキ処理など の施されたものから鉄だけを回収するのは難しく，結果的に 純鉄を混ぜることで希釈し再利用しているのが現状である. 従って現在の市中スクラップのリサイクル工程では，大規模 な装置と多大なエネルギーを必要とすることから，限られた 設備環境を持つ企業しか行えない年.3.

そこで本研究では，特殊環境下でのみ脆化する金属を複合 した粉末冶金材料を作製し，使用後のリサイクル工程におい て，特殊環境にさらすだけでほとんど機械加工を必要とせず に粉砕し，その粉末を回収してもう一度焼結するというコン セプトで，新たなリサイクルシステムの開発を試みた。この
システムのメリットとして次の二つのことが上げられる.一 つは粉末製品を溶解，希釈せずにリサイクルすることが可能 になり，省エネルギー，省資源につながること，もう一つは 接合部品にこの材料を用いることで解体作業が容易になり， リサイクル工程の作業量の低隇につながるということである.

このような解体法はアクティブティスアセンブリ ${ }^{4)}$ と呼ば れており，その原理は製品がそのライフサイクルの最終段階 で自ら分離解体するというものである.この実現のためには 製品開発の段階で物理的な分離解体に寄与するアクチュエー ターを内蔵する必要があり，製造コストの上昇は避けられな い。しかし, 解体時, リサイクルに要するエネルギーを低減 できるので，ライフサイクルコストは低減されると考えられ る.アクティブティスアセンブリの例としては, アクチュ エーターとしてバネを用い，キーとなる部分をはずすことで バネが解放されて部品がバラバラになるよう設計されたもの, また同じくアクチュエーターとして特定の溶剂にのみ溶解す る熱可塑性ポリマーを用い，その溶郕を用いることで，選択 
的な分離ができるようにしたものなどがあげられる．

Fig.1に具体的なフローチャートを示す. まず，鉄中にアク チュエーターとして水素化しやすい金属(Mとする)をネット 状に分散させた試料を作製する。これを製品として利用した 後に, 水素雾囲気中で高温保持することで金属 $M$ を水素化さ せ，その際の体積增加によって鉄の粒界部で選択的にクラッ クを生じさせ，全体を粉研させることができる．粉砕した粉 は鉄であり，その周囲には金属 M が付着しているため,これ を再び焼結させてはじめと同様に金属Mがネット状に分散し た試料を作製することができ，再び製品として使用すること ができる。

本研究では, 水素化しやすい金属として希土類金属のTbを 選んだ。希土類金属は水素吸蔵合金として用いられている5 ように，水素との化合物を作りやすく，その際の体積増加率 も大きい. なかでも Tbは酸化しにくく，濡れ性がよいという 特徴もあるため, 今回の実験には最適であると判断した.

本研究の目的は, 上記で示したリサイクルシステムが可能 かどうかを調へることである．まず焼結の温度や保持時間な どを変えることで，Tbがネット状に分散した試料の作製を試 みた. 次にその組織を持った試料が水素雾囲気中での熱処理 によってどのような変化を起こすかについて組織観察などを 行った.これらの結果について報告する.

\section{2 実験方法}

\section{1 試料作製方法}

用いた試料はいずれも市販のものであり，Fe粉は侏神戸製 鋼製のアトメル 300M， Tb は侏フルウチ化学製である.

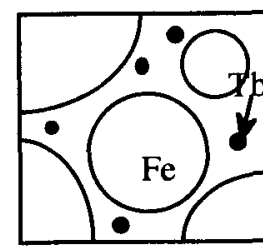

Addition $\mathrm{Tb}$ powder to $\mathrm{Fe}$

Consolidating

by the use of

Pseudo-HIP

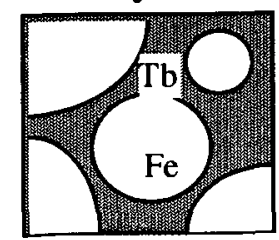

Dispersion Tb into the particle boundaries of $\mathrm{Fe}$

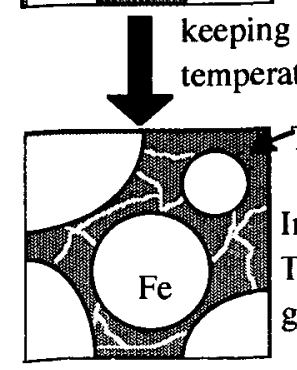

at high in $\mathrm{H}_{2}$ gas

Removing $\mathrm{H}_{2}$ gas, consolidating by th use of Pseudo-HIP again

Increasing volume of Tb by absorbing $\mathrm{H}_{2}$ gas, pulverizing

Fig.1 Flow chart of this system.
まずFe粉と、あらかじめ乳鉢を用いて細かくしておいた $\mathrm{Tb}$ 粉を目的組成になるように混合した。その混合粉末を内径 $18 \mathrm{~mm}$ ，深さ $80 \mathrm{~mm}$ の焼入鋼製の円筒型のダイスにいれ，手動 式油圧プレス機を用いて，上下方向に350MPaの荷重をかけ， 直径 $18 \mathrm{~mm}$, 高さ約 $10 \mathrm{~mm}$ の円筒形の粉末混合ペレットを作製 した.

このペレットをPseudo-HIP 法6-8) を用いて焼結した.PseudoHIP 法とは試料をヒーターとともに砂の中に埋め込み上から ピストンを用いて圧力をかけることにより，試料に疑似静水 圧をかけながら焼結の行える装置であり，絰密な試料を作製 できるという特徴を持っている. 本研究では電動式油圧プレ 又機を用いて 100MPaの荷重をかけながら，所定の温度で所 定時間保持することにより試料を作製した。

\section{2 水素化処理方法}

作製した試料を水素化させる方法として，水素フロ一装置 を用いた．Fig.2に装置の概略図に示すように，試料をいれた 高温炉の中に水素を流し続け，炉の中を絶えず0.1MPaに保つ ことができるようになっている．この装置を用いる利点は， 試料が水素を吸収して水素圧が減少し水素化が充分行えなく なることを防げるということである。本研究では，この装置 で 673Kで 7.2ks 保持することによって, 試料の水素化を試み た.

\section{3 実験結果}

TbはFeに比べて高価な金属であるので,できるたけ少量の Tbが試料全体をネット状に分散できるような条件を調べた。 焼結温度が低いか保持時間が短い場合は全体的にTbが分散せ ず，また焼結温度が高いか保持時間が長い場合にはFeが粗大 化してしまい，網目状に広がらない，以上のような難点を克 服すへく，Tbの割合を 1at\% から 5at\%，焼結温度を $1273 \mathrm{~K}$ お よび1673K，その温度での焼結時間を600sから 7.2ks と様々に

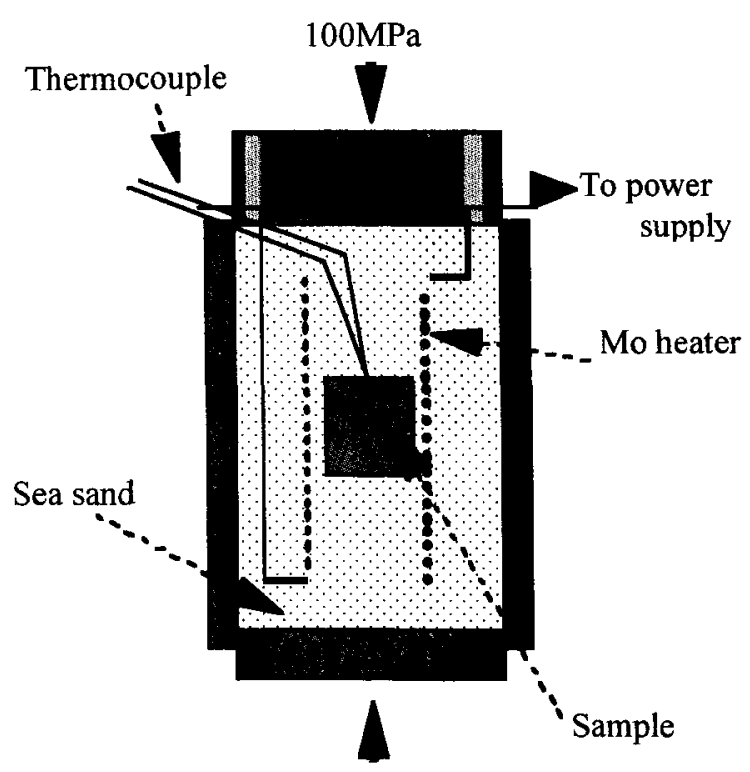

Fig.2 Schematic drawing of a Pseudo-HIP apparatus. 


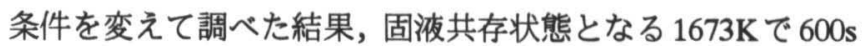
保持したときに, $2 \mathrm{at} \%$ という少ない量でTbをネット状に分散 させることができた. Fig.3にその試料の走査型電子顕微鏡 (SEM)による組織写真を示す. 試料全体に Tbがネット状に分 散し, そのネットの大きさが鉄の粒径である50 $\mu \mathrm{m}$ とほぼ同じ であることから,鉄の粉末界面に分散していることが分かる.

次に水素フローにより水素化を行い, その組織変化を観察 した. Fig.4 a),b) に水素フロー前と水素フロー後の光学顕微 鏡, および c),d)にSEMによる組織観察結果を示す. 光学顕微 鏡の写真から，水素フローによって鉄の粒界部分に選択的に クラックが生じているのが分かる.また SEMの写真からは, $\mathrm{Tb}$ のみが微粉化し, 特に試料表面近傍では $1 \mu \mathrm{m}$ 以下の粒に粉 砕されているのが分かる。これは一般的な水素吸蔵合金など に見られる微粉化現象と同じであり, 水素化に伴う体積膨張 と脆化が起こっているものと言える. 特に試料表面において は内部と違って余剩空間が大きく，そのために微細な粒状に なって存在したものと考えられる.

さらに水素フロー前後のビッカース硬さの変化を求めたと ころ, 水素フローによってビッカース硬さが $1100 \mathrm{HV} 1$ から 800HV1 程度まで減少していた．ここから，Tbが水素化して ネット部分にクラックが生じることにより, 全体的に脆化し ていることが分かる.

以上の結果から, 水素フローを行うことによって Tbの部分 に選択的にクラックが生じて全体的に脆化する事は分かった. しかしながら, フローチャートで示したように自ら破壊する ということは起こらなかった.

a)

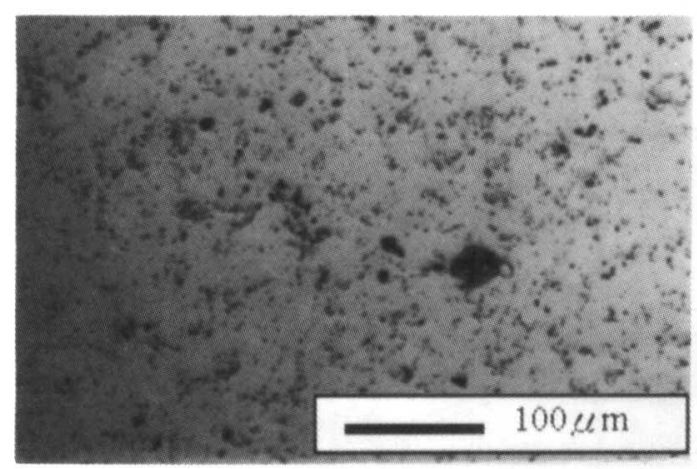

c)

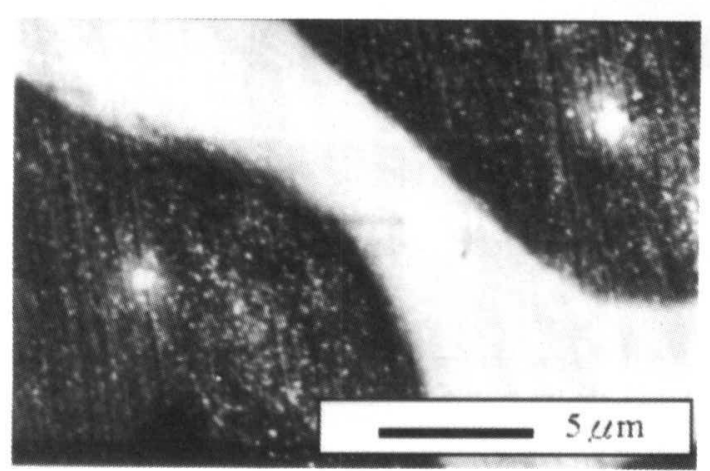

この試料を，Fig.5 に示すような餅つき型のダイスにいれ， 手動式油圧プレス機を用いて荷重をかけることで粉末状にす ることができた.そこで，この方法によって回収できた粉末

a)

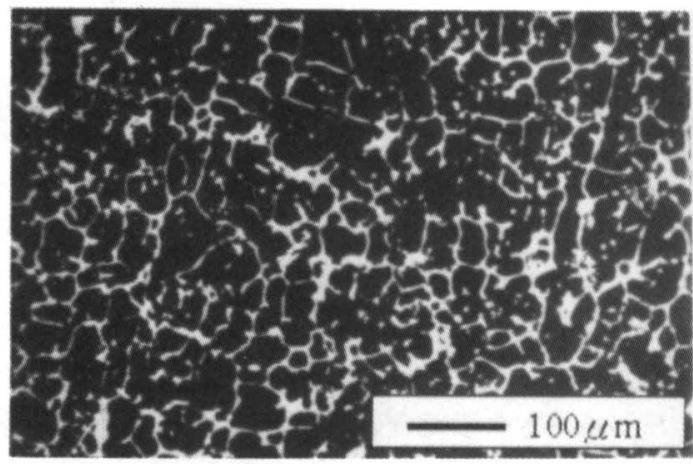

b)

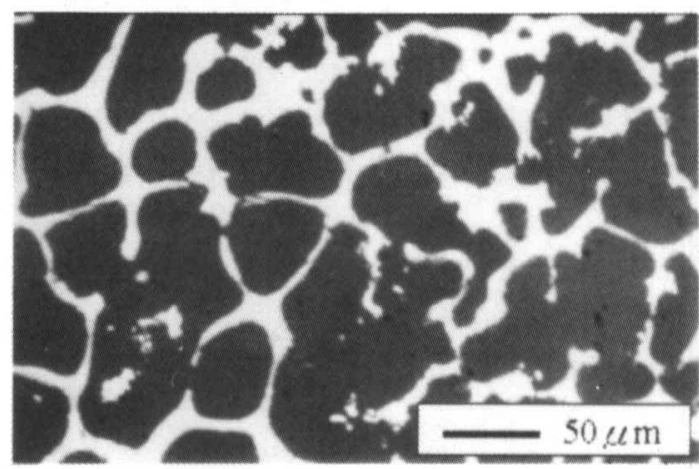

Fig.3 Scanning electron microscopic images of $\mathrm{Fe}-2$ at $\% \mathrm{~Tb}$ sintered by the use of P-HIP, a) low magnification and b) high magnification.

b)

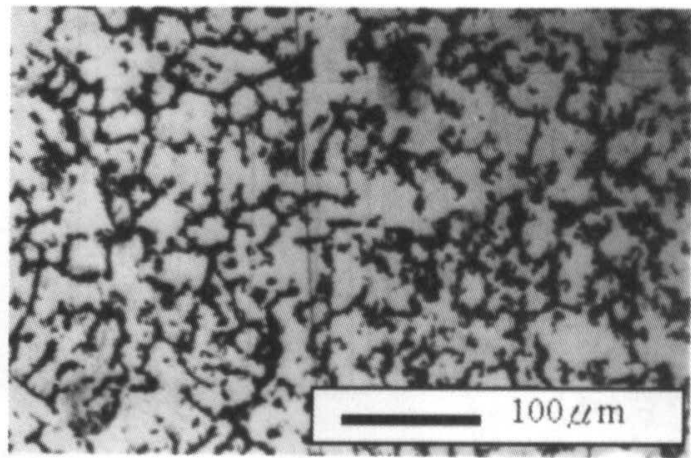

d)

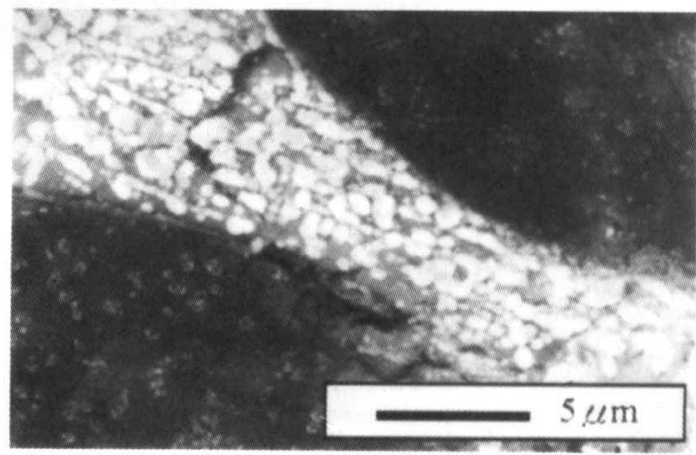

Fig.4 Optical micrographs and scanning electron microscopic images of Fe-2at\% Tb sintered by the use of P-HIP, a) c) as HIPed and b) d) annealed under hydrogen flow condition. 
を，もう一度同じく成型して焼結した. 焼結の温度，保持時 間はともに, 元の試料と同じく $1673 \mathrm{~K} て ゙ 600$ sとした. Fig.6に, この方法でできた試料のSEMによる組織観察結果を示す.一 部分ネット部分が切れているものの，全体的にはほぼ元と同 じ組織が得られた。このことから, 本材料が繰り返し使用で き, 繰り返し後もほぼ同じ組織を持った試料を得られること が分かった。

\section{4 考察}

本研究においてはFig.4で示したように水素処理によって試

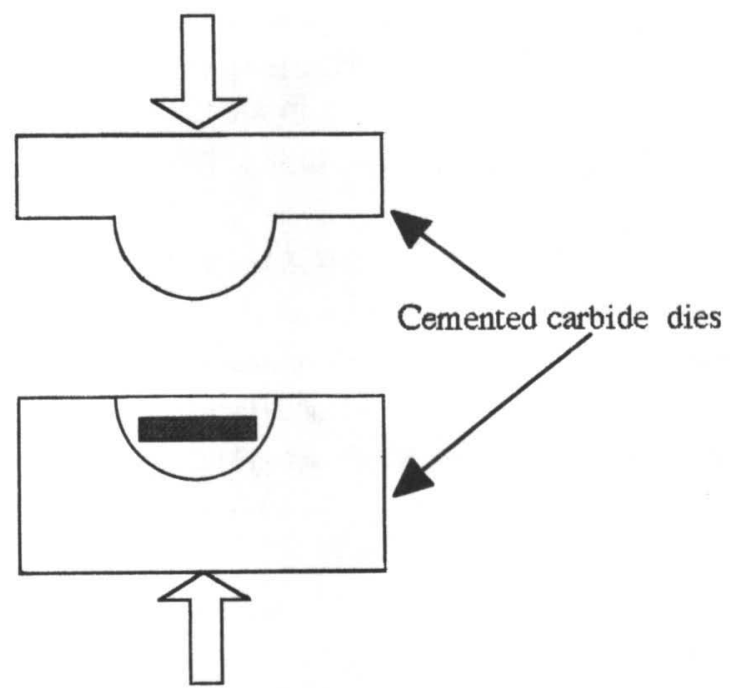

Fig.5 Scheme of a cemented carbide dies.

a)

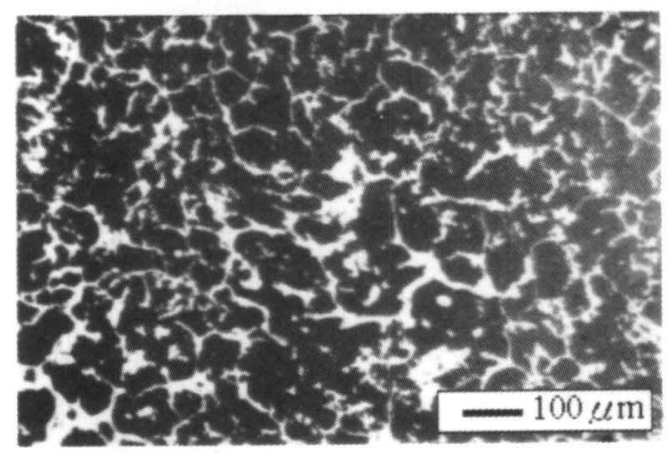

b)

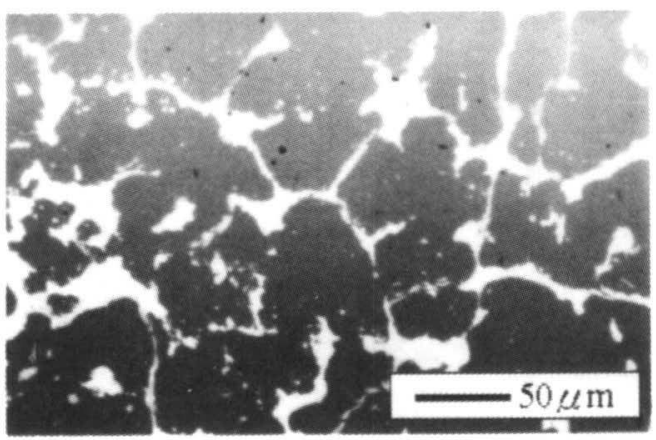

Fig.6 Scanning electron microscopic images of $\mathrm{Fe}-2 \mathrm{at} \% \mathrm{~Tb}$ reconsolidated by the use of P-HIP after pulverizing, a) low magnification and b) high magnification.
料表面の脆化は見られるものの，それが内部におよび，自己 分解するということは起こらなかった. Fig.7に 673K で 7.2ks 水素フローを行った際の, 試料の縦断面のSEMによる組織写 真を示す. $7.2 \mathrm{ks}$ の水素フローにおいては, $200 \mu \mathrm{m}$ 程度の深さ までしか水素が拡散しておらず，そのために全体的な脆化に 至らなかったことが分かる，そこで，どのような条件にすれ ば水素が内部にまで拡散するかを以下に示す.

まず, $673 \mathrm{~K} て ゙ ~ 3.6 \mathrm{ks}, 7.2 \mathrm{ks}, 14.4 \mathrm{ks}, 21.6 \mathrm{ks}$ および $57.6 \mathrm{ks}$ の水 素フローを行い，それぞれの場合の拡散距離 $\mathbf{x}$ と，時間の平 方根 $\mathrm{t}^{1 / 2}$ との関係を Fig. 8 に示す. 水素の $\mathrm{Tb}$ への拡散係数を D とすると, $\mathrm{x}$ と $\mathrm{t}$ との間には

$$
x=\sqrt{2 D t}
$$

の関係" があり, Fig.8のグラフの傾きから D を計算すると D $=0.95 \times 10^{-12} \mathrm{~m}^{2} / \mathrm{s}$ となる.つまり, 本研究において作成した試 料において深さ $1 \mathrm{~mm}$ まで拡散させるには, 約 $262.8 \mathrm{ks}$ の水素 フローを行う必要がある. 希土類系水素吸蔵合金として知ら れている $\mathrm{LaNi}_{5}$ に対しての水素の拡散定数の文献值 ${ }^{10}$ は $3 \times 10^{-10}$ $\mathrm{m}^{2} / \mathrm{s}(423 \mathrm{~K})$ となっており, 本研究で得られた值は温度が高い

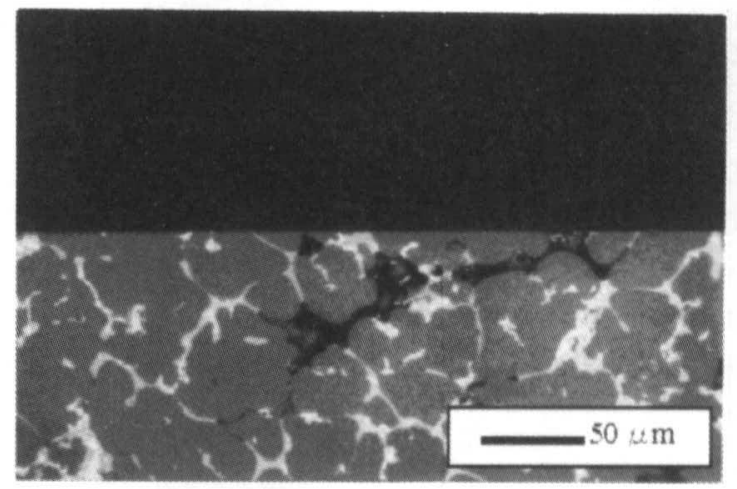

Fig.7 Scanning electron microscopic image of cross section vertical to hydrogen diffusion in $\mathrm{Fe}-2 \mathrm{at} \% \mathrm{~Tb}$ after hydrogen heat treatment.

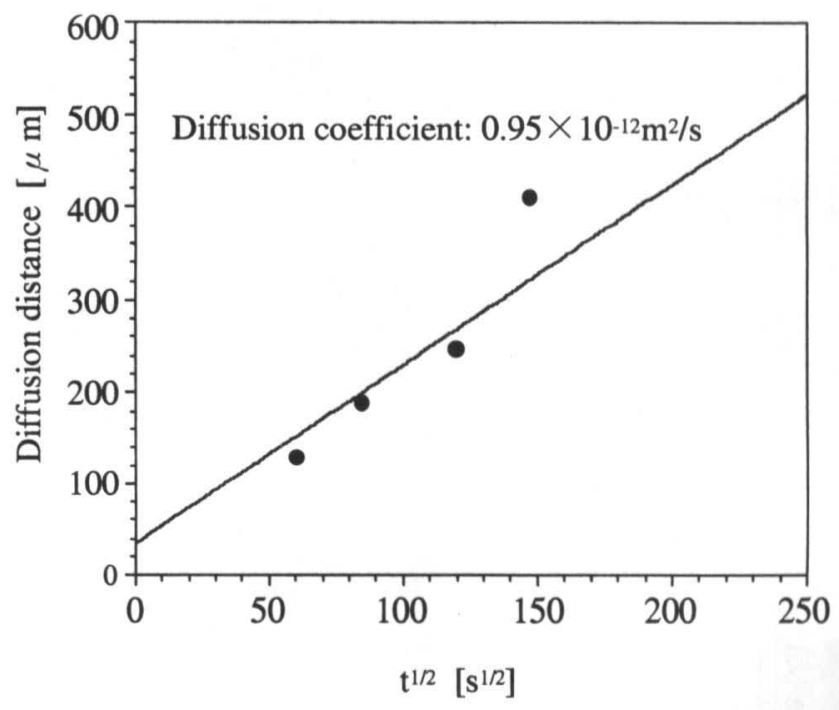

Fig.8 Diffusion distance vs. $\mathrm{t}^{1 / 2}$. 
にも関わらず，それに比へて2 2桁ほど小さい．また文献に示 されている $\alpha$ 鉄中の水素の拡散係数 ${ }^{11)}$ は $1.93 \times 10^{-8} \mathrm{~m}^{2} / \mathrm{s}(673 \mathrm{~K})$ となっており, 水素の Tbへの拡散が水素化を律速することが わかる。

また水素吸蔵合金そのものをリサイクルを目的とした材料 に使うことも考えられるが，分散させたほうがコストも低く なり，製品の機械的強度を保持できるというメリットがある. 実際に, 水素熱処理前の Fe-2at\% Tbについて圧縮試験を行っ たところ，マトリックスである鉄に比べて，降伏応力・破壊 応力ともに若干の上昇がみられた. 同時に10\%をこえる歪み も生じているので, 加工性についての問題もないと思われ， 機械的特性の变化が少ないことがわかった。

以上のことから，今回示したシステムの実現のためには， 水素の拡散係数の大きい金属をアクチュエーターとして用い 自己粉砕を起こさせることが必要であると考えられる。ささら に, 今後広く工業的に受け入れられるためには, 単価が安い ことも求められる.例としてはミッシュメタルや, 希土類系， およびTi系水素吸蔵合金などが考えられる。

\section{5 まとめ}

(1) Fe-2at\%Tbにおいて，1673Kで 600s という焼結条件におい て希土類金属の $\mathrm{Tb} か ゙ \mathrm{Fe}$ の一次粒界上にネット状に分散し ている組織をもった試料が作製された。

(2) (1)で作成できた試料について，水素雾囲気中で熱処理を 行うことにより Tbの部分だけに選択的にクラックが生じ, 試料の全体的な脆化か見られた。

(3) 脆化した試料を粉砕したあと，もう一度焼結することで， 元と同様の組織を有する試料を作製することができた。

\section{謝辞}

本研究は日本学術振興会 未来開拓学術研究推進事業におけ
るプロジェクト「環境負荷低隇を目的とした新しい自律分散 型都市エネルギーシステム」(プロジェクト番号: JSPS-RFTF 97P01002)の一環として行われました.ここに感謝の意を表し ます.

\section{文献}

1）坂田直紀 : "鉄鋼業におけるリサイクルの現状と課題", 日 本鉄鋼協会白石記念講座資料, (1992.11.27).

2) A.W.Crmb and R.J.Fruhan: I\&SM, 18(1991)11.

3) 出向井ら: "金属スクラップからの不純物の除去", 日本金 属学会, (1990.1.25)

4) C.B.Boks and E.Tempelman: "Final report of the Delphi study on future disassembly and recycling technology for the electronics and automotive industry", TU Delft April, (1997).

5) 内田裕久, 久慈俊郎: 希土類系水素吸藏合金, 金属 1, Vol.68, No.1, pp.29.

6) 新宮秀夫: "ニューセラミックス ", 2(1990)670.

7) P.H.Shingu and K.N.Ishihara: "A pseudo-HIP process applicable for the near-net-shape synthesis of inter-metallic compounds", J. Jpn. Soc. Powder Powder-Metall. (Japan), 37(1990)670-673.

8) T.Yamamoto, A.Otsuki, K.Ishihara and P.H.Shingu: "Synthesis of near net shape high density TiB/Ti composite", Mater. Sci. Eng., A239-240(1997)647-651.

9) 竹内伸, 井野博満, 古林英一: "金属材料の物理", 日刊工業 新聞社, (1992)37-38.

10) C.A.Ward, B.Farahkhsh and R.D.Venter: "Absoroption Rate at the Hydrogen-Metal", Z. Phys. Chem. Neue Folge, 147(1986)89101.

11) E.Fromm, H.Speck, H.Jehn and G.Horz: "Physik Daten (Physics data.)" Karlsruhe: Fach informations zentrum Energie, Physik, Mathematik GmbH, Nr.5-13(1981). 